\title{
Oestrogen, ocular function and low-level vision: a review
}

\section{Claire V Hutchinson, James A Walker ${ }^{1}$ and Colin Davidson ${ }^{2}$}

College of Medicine, Biological Sciences and Psychology, University of Leicester, Leicester LE1 9HN, UK ${ }^{1}$ Harvard Medical School, Center for Human Genetic Research, Massachusetts General Hospital, Boston, Massachusetts 02114, USA

${ }^{2}$ Division of Biomedical Sciences, St George's Medical School, University of London, London SW17 ORE, UK
Correspondence should be addressed to $\mathrm{C} V$ Hutchinson Email

ch190@le.ac.uk

\begin{abstract}
Over the past 10 years, a literature has emerged concerning the sex steroid hormone oestrogen and its role in human vision. Herein, we review evidence that oestrogen (oestradiol) levels may significantly affect ocular function and low-level vision, particularly in older females. In doing so, we have examined a number of vision-related disorders including dry eye, cataract, increased intraocular pressure, glaucoma, age-related macular degeneration and Leber's hereditary optic neuropathy. In each case, we have found oestrogen, or lack thereof, to have a role. We have also included discussion of how oestrogen-related pharmacological treatments for menopause and breast cancer can impact the pathology of the eye and a number of psychophysical aspects of vision. Finally, we have reviewed oestrogen's pharmacology and suggest potential mechanisms underlying its beneficial effects, with particular emphasis on anti-apoptotic and vascular effects.
\end{abstract}

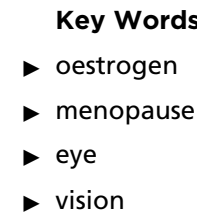

Journal of Endocrinology (2014) 223, R9-R18

\section{Introduction}

Emerging evidence suggests that appropriate levels of the sex steroid hormone oestrogen (and in particular oestradiol $\left.\left(\mathrm{E}_{2}\right)\right)$ may be a significant factor in the maintenance of healthy visual function, particularly in older females. To our knowledge, with the exception of one Cochrane database study (Gharaibeh et al. 2011), which reviewed the use of oestrogen in treating traumatic hyphema (injuryrelated blood in the anterior chamber of the eye), there are no recent reviews on the use of oestrogen in the treatment of visual dysfunction in older adults. In this review, we examine evidence for oestrogen's importance in human vision, with particular emphasis on its potential as a therapeutic target in postmenopausal vision.

\section{Oestrogen and its pharmacology}

There are three main types of oestrogen (Fig. 1): oestrone $\left(E_{1}\right), E_{2}$ and oestriol $\left(E_{3}\right)$, and their levels are determined by oestrus cycle, age and pregnancy. $\mathrm{E}_{1}$ is most abundant during menopause and post-menopause, $\mathrm{E}_{2}$ in younger ( $<45$ years) women and $\mathrm{E}_{3}$ during pregnancy. There are also numerous other naturally occurring oestrogens. Although the remit of this review concerns the relationship between oestrogen and vision in females, it is worth noting for completeness that oestrogens are also present in males. Indeed, they play a major role in many metabolic functions in men (de Ronde et al. 2003). It has even been suggested that many biological effects attributed to testosterone may actually represent the effects of oestrogens (de Ronde et al. 2003). Although, like females, oestrogen levels decline in older men, the decline is relatively modest (Orwoll et al. 2006). Furthermore, older (more than 65 years) males may actually have higher $\mathrm{E}_{2}$ levels than their older female counterparts (Carlson \& Sherwin 2000).

Oestrogens can easily diffuse across cell membranes and act on the cytosolic oestrogen receptors, ER $\alpha$ (ESR1)

Published by Bioscientifica Ltd 


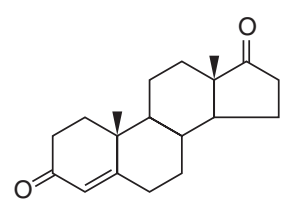

Androstenedione

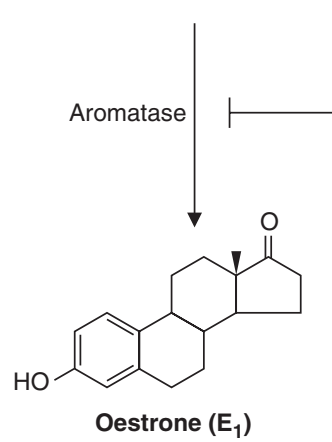

Oestrone $\left(E_{1}\right)$

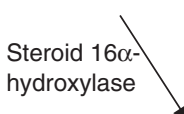

$16 \alpha-$ Hydroxysterone

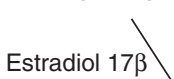

dehydrogenase

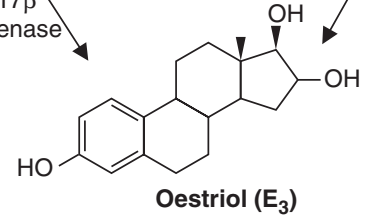

Figure 1

Synthesis of oestrogens. Structures of the three main types of oestrogen are shown: $E_{1}$, oestradiol $\left(E_{2}\right)$ and $E_{3}$. Oestrogens are synthesised from androgens, testosterone and androstenedione, by the enzyme aromatase. The aromatase inhibitor anastrozole is used in the treatment of breast cancer after surgery to inhibit the synthesis of oestrogens. Oestrogens are produced primarily in the ovaries, but also in smaller amounts in liver, adrenal glands, breast and neurons.

and ER $\beta$ (ESR2). Oestrogens and their receptors (ERs) regulate diverse signalling pathways to modulate neuronal differentiation, influence cell migration, survival and death, and synaptic plasticity of neurons (Fig. 2; Arevalo et al. 2011). The mechanisms of oestrogen action include both nuclear-initiated cell-signalling and membrane/ cytoplasm-initiated cell-signalling. In the absence of a ligand, the classical ERs (ER $\alpha$ and ER $\beta$ ) are predominantly cytosolic. Upon oestrogen activation, they relocate to the nucleus and interact with cis-regulatory elements of target genes by directly binding to oestrogen-response elements (EREs) or indirectly through their interaction with other DNA-bound transcription factor complexes. The ERs thereby facilitate the transcription of target mRNAs, including those encoding proteins important for cell survival and neuronal function. Recently, a
G protein-coupled oestrogen receptor (GPER - previously known as GPR30) has been identified, which acts at the cell surface and is found in a variety of tissues (Hazell et al. 2009, Filardo \& Thomas 2012). Whereas the nuclear receptors mediate the long-term ('genetic') effects of oestrogen, GPER probably mediates some of the more rapid 'pre-genomic' signalling actions. The non-classical ER, GPER, as well as a fraction of ER $\alpha$ and ER $\beta$, is located at the cell membrane and can therefore be rapidly activated upon ligand binding (Manavathi \& Kumar 2006). ERs form complexes with G-proteins, glutamate receptors, receptor tyrosine kinases (RTKs), such as insulin-like growth factor 1 receptor and epidermal growth factor receptor, and nonRTKs (e.g. Src) to regulate a wide variety of cellular functions. For example, $E_{2}$ and $E R \alpha$ have recently been shown to control neuron morphology by regulating actin remodelling through extra-nuclear signalling via the RHO and RAC1 pathways (Sanchez \& Simoncini 2010). By influencing the RAS/ERK, PI3K/AKT and cAMP/PKA pathways, which ultimately can affect events in the nucleus, the membrane ERs likely connect the nongenomic actions of oestrogens to its genomic responses.

\section{The eye}

Oestrogen is abundant in the mammalian eye. ERs have been found in the retina, cornea, lens, iris, ciliary body, conjunctiva, lacrimal and meibomian glands of male and female eyes across a number of species including humans, rodents and rabbits (Wickam et al. 2000, Gupta et al. 2005). It is unsurprising therefore that oestrogen levels may impact vision through its effects on the eye, from the ocular surface to the retina.

The presence of ERs in the conjunctiva, lacrimal and meibomian glands suggests that oestrogen may modulate tear production (Versura \& Campos 2005). For example, the prevalence of dry eye syndrome is more common in older women compared with older men, and women with glaucoma are more likely to suffer from this condition than men (Erb et al. 2008). Although its causes are multifactorial, increased prevalence in older women may reflect postmenopausal oestrogen $\left(\mathrm{E}_{2}\right)$ reduction. Tear production decreases after menopause (Altintas et al. 2004). Although some studies have found that hormone replacement therapy (HRT) leads to a decrease in tear function (Schaumberg et al. 2001, Uncu et al. 2006), the majority have shown that dry eye improves after HRT (Affinito et al. 2003, Guaschino et al. 2003, Altintas et al. 2004, Taner et al. 2004, Coksuer et al. 2011). In addition, topical $\mathrm{E}_{2}$ drops appear to alleviate dry eye symptoms http://joe.endocrinology-journals.org DOI: 10.1530/JOE-14-0349
C 2014 Society for Endocrinology Printed in Great Britain
Published by Bioscientifica Ltd. 


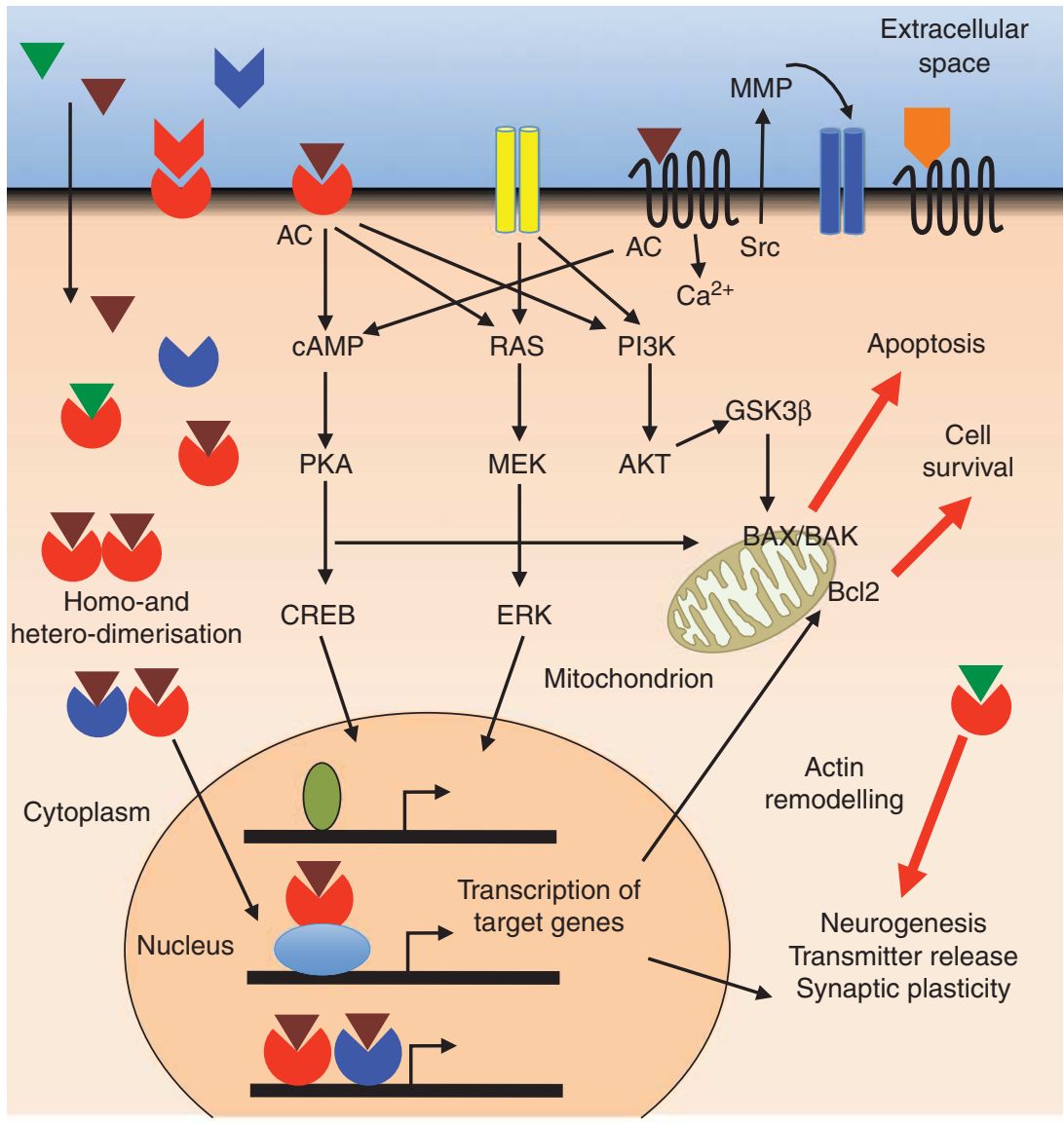

\begin{tabular}{|c|c|c|}
\hline & Oestrone $\left(E_{1}\right)$ & EGFR \\
\hline & Oestradiol $\left(E_{2}\right)$ & Transcription factors e.g. \\
\hline & $\mathrm{ER} \alpha$ & AP1, Sp1 and NF-кB \\
\hline & ER $\beta$ & Other transcription factors \\
\hline 1000 & GPER & Anti-oestrogens, SERMS \\
\hline & IGF1R & G15 \\
\hline
\end{tabular}

\section{Figure 2}

Oestrogen-regulated signalling pathways that could affect retinal function and health. The nuclear-initiated signalling response of oestrogens is mediated by the classical oestrogen receptors (ERs - ER $\alpha$ and ER $\beta$ ), which relocate to the nucleus after ligand binding and dimerisation. By binding to estrogen-response elements (ERE) at specific target genes, ERs can activate transcription. $E_{1}$ and oestradiol can also bind to ERs (ER $\alpha, E R \beta$ and G-protein-coupled oestrogen receptor (GPER)) located at the cell membrane and rapidly activate signalling pathways including the RAS/ERK, PI3K/AKT and cAMP/PKA pathways. These can influence transcription, cytoskeleton remodelling, apoptosis/cell survival as well as neuron-specific

(Sator et al. 1998). However, at present, there is insufficient basic experimental evidence to justify this treatment. In addition, animal studies have demonstrated increased apoptosis in ocular surface epithelial cells in rats after ovariectomy, which was reduced after 3 months of $\mathrm{E}_{2}$ functions, such as transmitter release and synaptic plasticity. Dysregulation of these processes could be important in visual dysfunction. There is considerable cross-talk between ERs and other receptors such as insulin-like growth factor receptor (IGF1R) and epidermal growth factor receptor (EGFR). Note: oestrogen has a higher affinity for ER $\alpha$ than ER $\beta$. AC, adenylyl cyclase; PKA, protein kinase A, MMP, metalloproteinase, PI3K, phosphoinositide 3-kinase, GSK3 $\beta$, glycogen synthase kinase $3 \beta$. G15 is a GPER antagonist. A full colour version of this figure available via http://dx.doi. org/10.1530/JOE-14-0349.

therapy (Özcura et al. 2012). $\mathrm{E}_{2}$ has also been shown to ameliorate corneal epithelial inflammation in rodent models (Wang et al. 2012).

$\mathrm{E}_{2}$ has also been implicated in the health of the lens. There is an apparent weak protective association between

Published by Bioscientifica Ltd. 
use of oral contraceptive pill and the development of cortical cataract (Kanthan et al. 2010), a notion supported by evidence that $\mathrm{E}_{2}$ treatment prevents induced cataracts in rats (Hales et al. 1997, Chen et al. 2004). In addition, patients prescribed tamoxifen, a selective ER antagonist, for the treatment of breast cancer are more likely to develop cataracts (Paganini-Hill \& Clark 2000, Lee et al. 2004). There is also some evidence that HRT might reduce the risk of increased lens opacity and cataract development (Worzala et al. 2001), although this is still a matter of debate, as others report no effect (Altintas et al. 2004, Kanthan et al. 2010).

\section{Eye disease and the retina}

Oestrogen has been identified as a potential factor in agerelated diseases that affect the retina, such as glaucoma and age-related macular degeneration (AMD). Indeed, a recent review has concluded that oestrogen (at the proper dose) should be considered a potential therapy for glaucoma, particularly in menopausal women who suffer from the condition (Wei et al. 2012). The polymorphism of $E R \beta$ gene is associated with intraocular pressure (IOP) elevation in female patients with open-angle glaucoma (Mabuchi et al. 2010), and polymorphisms of $E R \beta$ increase its risk in males (de Voogd et al. 2008). There is also evidence that early menopause ( $<45$ years) may be associated with a higher risk of glaucoma (Hulsman et al. 2001). Later menopause ( $>54$ years) has been associated with a reduced risk of developing open-angle glaucoma (Pasquale et al. 2007). Postmenopausal women may be more susceptible to glaucoma because of the effects of oestrogen (specifically, reduced $\mathrm{E}_{2}$ levels) on IOP elevation. High IOP is a risk factor in the development of glaucoma. Women have significantly higher IOP than agematched men at/after the age of menopause (Ganley 1980, Pointer 2000, Altintas et al. 2004). A number of studies have therefore examined the utility of HRT for lowering IOP and, by extension, reducing glaucoma risk. These studies have indicated mixed results. Some report no effect of hormone therapy on IOP (Guaschino et al. 2003, Abramov et al. 2005), and one study (Khurana et al. 2006) found that HRT raises IOP in postmenopausal females with dry eye syndrome. However, most studies observed that hormone therapy significantly lowers IOP in menopausal (Sator et al. 1998) and postmenopausal women (Guaschino et al. 2003, Altintas et al. 2004, Uncu et al. 2006, Tint et al. 2010, Coksuer et al. 2011; data given in Table 1). This conclusion is supported by animal models, where it has been reported that $\mathrm{E}_{2}$ prevents retinal ganglion cell loss induced by acute IOP elevation in rats (Russo et al. 2008). Studies investigating the effects of normal cycling oestrogen on IOP have been inconclusive. Although an early study suggested that IOP is highest in the menstrual phase (when oestrogen is lowest; Salvati 1923), more recent studies have shown no change across the menstrual cycle (Qureshi et al. 1997, Seymenoğlu et al . 2011). Oestrogen has also been implicated in AMD in older females, where contraceptive use and postmenopausal HRT lower the risk of developing it. This is particularly the case for neovascular AMD (Haan et al. 2006, Feskanich et al. 2008).

Oestrogen has also been implicated in genetic retinal diseases such as Leber's hereditary optic neuropathy (LHON). LHON is a mitochondrial disease, caused by mutations in the genes encoding the subunits of NADH dehydrogenase within the mitochondrial genome. It is mostly prevalent in young men and is characterised by retinal ganglion cell degeneration and, consequently, optic atrophy and central vision loss. A recent study has shown that $\mathrm{E}_{2}$ was able to ameliorate mitochondrial dysfunction in a cell model of LOHN, which includes production of reactive oxygen species and apoptosis (Giordano et al. 2011). This suggests that in females, oestrogens may play a protective role on mitochondrial metabolism, thereby accounting for the prevalence of LHON in male.

\section{Visual psychophysical performance}

Little attempt has been made to assess the effects of oestrogen on behavioural (psychophysical) measures of vision. The findings of the limited number of studies that have been done so far are promising, in that some aspects of visual sensitivity do vary with oestrogen levels. A phytooestrogen-rich diet (e.g. flax and soy) may improve the performance on short wavelength-automated perimetry in postmenopausal females (Eisner \& Demirel 2011). There is also evidence that visual sensitivity improves in pregnancy, being greatest in the third trimester when oestrogen levels are at their highest (Akar et al. 2005). Contrast sensitivity is lower in postmenopausal than in premenopausal women (Siesky et al. 2008), particularly at high spatial frequencies (between 9 and 18 cycles/degree), and improves after hormone therapy (Guaschino et al. 2003). Contrast sensitivity may also vary with normal cycling oestrogen (Johnson \& Petersik 1987), being best towards the middle of the cycle when $\mathrm{E}_{2}$ levels in the blood are at their highest.

Published by Bioscientifica Ltd. 
Table 1 Effects of hormone replacement therapy (HRT) on intraocular pressure (IOP)

\begin{tabular}{|c|c|c|c|c|c|}
\hline \multirow[b]{2}{*}{ HRT treatment } & \multirow{2}{*}{$\begin{array}{l}\text { Treatment duration } \\
\text { at time of testing } \\
\text { experimental group }\end{array}$} & \multicolumn{2}{|c|}{ Cohort sizes } & \multirow[b]{2}{*}{ Effect on IOP } & \multirow[b]{2}{*}{ References } \\
\hline & & $\begin{array}{l}\text { Experimental } \\
\text { groups }\end{array}$ & $\begin{array}{l}\text { Control } \\
\text { groups }\end{array}$ & & \\
\hline Oestrogen + dydrogesterone & +12 months & 40 & 40 & $\begin{array}{l}\text { No difference between } \\
\text { experimental and control } \\
\text { groups }\end{array}$ & $\begin{array}{l}\text { Guaschino } \\
\text { et al. (2003) }\end{array}$ \\
\hline $\begin{array}{l}\text { Oestrogen }+ \text { progesterone } \\
\text { (95 participants) }\end{array}$ & $\geq 12$ months & 107 & 107 & $\begin{array}{l}\text { No difference between } \\
\text { experimental and control } \\
\text { groups }\end{array}$ & $\begin{array}{l}\text { Abramov et al. } \\
\text { (2005) }\end{array}$ \\
\hline \multicolumn{6}{|l|}{ Oestrogen (12 participants) } \\
\hline $\begin{array}{l}\text { Oestrogen }+ \\
\text { medroxyprogesterone }\end{array}$ & $\begin{array}{l}\text { Pre-treatment and } \\
\quad+6 \text { and } 12 \text { months }\end{array}$ & 19 & None & No effect & $\begin{array}{l}\text { Uncu et al. } \\
\qquad(2006)\end{array}$ \\
\hline Tibolone & & 6 & & No effect & \\
\hline Oestrogen patch & & 5 & & $\begin{array}{l}\text { No change after } 6 \text { months. } \\
\text { Decrease relative to } \\
\text { pre-therapy measurement } \\
\text { after } 12 \text { months treatment }\end{array}$ & \\
\hline $\begin{array}{l}\text { Oestrogen }+ \\
\text { methylprogesterone }\end{array}$ & $\begin{array}{l}\text { Pre-treatment and } \\
\text { intermittently over } \\
12 \text { months }\end{array}$ & 13 & None & $\begin{array}{l}\text { IOP increased over 12-month } \\
\text { treatment period }\end{array}$ & $\begin{array}{l}\text { Khurana et al. } \\
\qquad(2006)\end{array}$ \\
\hline Oestrogen + drospirenone & $\begin{array}{l}\text { Pre-treatment and } \\
\quad+6 \text { months }\end{array}$ & 34 & None & $\begin{array}{l}\text { Decrease relative to pre-therapy } \\
\text { measurement }\end{array}$ & $\begin{array}{l}\text { Coksuer et al. } \\
\text { (2011) }\end{array}$ \\
\hline Oestrogen & $\begin{array}{l}\text { Pre-treatment and } \\
\quad+3 \text { and } 6 \text { months }\end{array}$ & 24 & None & $\begin{array}{l}\text { Decrease relative to pre-therapy } \\
\text { measurement. Improvement } \\
\text { plateaued after } 3 \text { months }\end{array}$ & $\begin{array}{l}\text { Affinito et al. } \\
\qquad(2003)\end{array}$ \\
\hline Medroxyprogesterone & & 24 & & No effect & \\
\hline HRT (combination unknown) & $\begin{array}{l}\text { Pre-treatment and } \\
\quad+2 \text { months }\end{array}$ & 15 & None & $\begin{array}{l}\text { Decrease relative to pre-therapy } \\
\text { measurement }\end{array}$ & $\begin{array}{l}\text { Altintas et al. } \\
\qquad(2004)\end{array}$ \\
\hline Oestrogen & Variable & 33 & 172 & $\begin{array}{l}\text { Lower in experimental group } \\
\text { than in controls }\end{array}$ & $\begin{array}{l}\text { Tint et al. } \\
\quad(2010)\end{array}$ \\
\hline Oestrogen + progesterone & & 58 & & $\begin{array}{l}\text { Lower in experimental group } \\
\text { than in controls }\end{array}$ & \\
\hline
\end{tabular}

\section{Visual side effects of breast cancer treatment}

A good deal of direct evidence for the effects of oestrogen on ocular function and visual sensitivity can be found in studies of vision in those undergoing treatment for hormone receptor-positive breast cancer. Hormone receptor-positive breast cancer is typically treated pharmacologically using selective ER modulators (SERMs), such as tamoxifen, or aromatase inhibitors, such as anastrozole. Both treatments act by reducing the effects of oestrogen and both have been shown to produce visual (Eisner \& Luoh 2011) and possibly some cognitive (Espeland et al. 2010) side effects. Tamoxifen is a selective ER antagonist. Its use, even for short periods, increases the risk of cataract (Paganini-Hill \& Clark 2000, Lee et al. 2004), and cystoid spaces in the fovea become apparent within a year of treatment (Nayfield \& Gorin 1996). It may cause optic neuritis (Noureddin et al. 1999, Colley \& Elston 2004) and reduce the size of the optic cup, which has been attributed to astrocytic swelling caused by tamoxifen-induced oestrogen reductions (Eisner et al. 2007). Some women undergoing tamoxifen treatment exhibit anomalous colour sensitivity (Eisner et al. 2004, Eisner \& Incognito 2006, Salomao et al. 2007). Aromatase inhibitors are also used to treat early-stage breast cancer. The most commonly used is anastrozole, which inhibits oestrogen synthesis by binding to aromatase enzymes and interfering with steroidal hydroxylation (Fig. 1). Although SERMs such as tamoxifen are prescribed to women of all ages, aromatase inhibitors are only successful in postmenopausal women as they fail to block oestrogen production sufficiently in premenopausal patients. Although anastrozole causes fewer visual side effects than tamoxifen, anomalous colour vision is common (Eisner \& Toomey 2008) and vitreo-retinal traction is increased (Eisner et al. 2009).

\section{Potential mechanisms of oestrogen cell protection}

The role of oestrogens as neuroprotective agents in regulating the balance between cell survival, proliferation and apoptosis is mediated by both nuclear and nonnuclear mechanisms. $E_{2}$ can modulate the expression of

Published by Bioscientifica Ltd 
the anti-apoptotic proteins BCL2 and/or BCL-XL (the long isoform of BCL-X) in neurons and, conversely, can downregulate the expression of the pro-apoptotic BAD or NIP2, a negative regulator of BCL2 (reviewed in Simpkins et al. (2010)). The finding that ERs, particularly ER $\beta$, localise to mitochondria suggests they play important roles in this organelle (Klinge 2008). Through modulating RAS/ERK, PI3K/AKT and PKA signalling pathways, as well as regulating intracellular calcium levels, oestrogen signalling can impinge upon mitochondrial function and mediate apoptosis/cell survival of neurons (Queseda et al. 2008, Simpkins et al. 2010, Azcoitia et al. 2011, Vasconsuelo et al. 2011). Oestrogen can also have protective effects through the brain's immune cells, microglia, and through oligodendrocytes, which help to maintain the myelination of some neurons (e.g. retinal ganglion cells) through the ER $\beta$ receptor (Crawford et al. 2010).

$\mathrm{ER} \alpha$ receptor activation is anti-inflammatory, leading to cell protection, while ER $\beta$ receptor activation may facilitate recovery (Tiwari-Woodruff \& Voskuhl 2009). These effects may be mediated through an inhibition of apoptosis (Jover-Mengual et al. 2007, Yang et al. 2010). $\mathrm{E}_{2}$ protects against retinal ganglion cell death (Nakazawa et al. 2006) and glutamate-induced toxicity (Yamashita et al. 2011, Nixon \& Simpkins 2012) in rodents. It increases retinal blood flow and protects the retinal nerve fibre layer in ovariectomised rats (Deschênes et al. 2010) and prevents swelling in rat retinal glial cells (Neumann et al. 2010). Genistein, an isoflavone that binds to ERs, protects the retina against ischaemia (Kamalden et al. 2011) and the ER $\beta$-selective agonist GTx-822 protects retinal pigment epithelial cells from oxidative stress-induced apoptosis (Giddabasappa et al. 2010). Similar effects have been shown for the oestrogen agonist paeoniflorin (Wankun et al. 2011).

The protective effects of oestrogen levels in the blood vessels (Fig. 3) may be particularly important for visual diseases such as glaucoma, for which ocular hypertension is a significant risk factor (Gordon et al. 2002, Kass et al. 2002). Indeed, this account fits with the notion that use of HRT and contraceptive pill protects against neovascular AMD (Haan et al. 2006, Feskanich et al. 2008). Oestrogen interacts with endothelial cells, which surround the lumen of blood vessels, and smooth muscle cells, which control contraction of blood vessels. Within blood itself, oestrogen interacts with platelets, involved in haemostasis, and leukocytes, the blood's immune cells (van der Spuy \& Pretorius 2012). Indeed, some of the protective effects of oestrogen on ocular function may be due to its direct positive effects on arterial function. In humans,

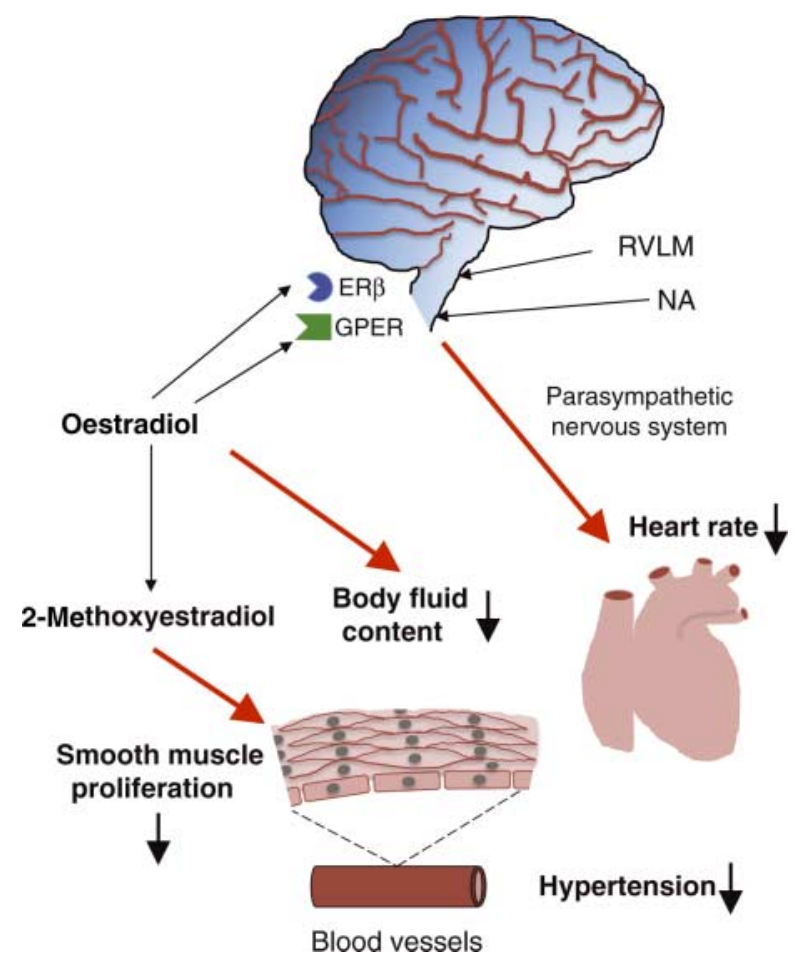

Figure 3

Putative cardiovascular effects of oestrogen. Oestradiol activates two brain areas to decrease heart rate via the parasympathetic nervous system. The rostral ventrolateral medulla (RVLM) is activated via ER $\beta$ receptors and the nucleus ambiguous (NA) is activated via GPER. This decreased heart rate might decrease hypertension-related visual pathologies. One oestradiol metabolite is 2-methoxyestradiol, which can decrease smooth muscle cell proliferation in blood vessels, also reducing hypertension. A full colour version of this figure available via http://dx.doi.org/10.1530/JOE-14-0349.

choroidal circulation is lower in postmenopausal women compared with pre-menopausal women (Kavroulaki et al. 2010), and hormone therapy has been shown to improve blood flow in the inferotemporal retinal artery, peripapillary retina and the optic nerve head rim. Similar effects have been observed in rats treated with $\mathrm{E}_{2}$. Increased retinal blood flow increases optic nerve head rim volume in postmenopausal women (Deschênes et al. 2010). It has also been suggested that changes in ocular (retinal and choroidal) blood flow may affect visual characteristics such as contrast sensitivity (Shoshani et al. 2011). This is important given that contrast sensitivity decreases after menopause, improves after HRT and is affected by normal cycling oestrogen. Coupled with evidence that reduced retinal blood flow may act as a precipitant in the development of glaucoma and AMD (Harris et al. 1999, Flammer et al. 2002, Pinto et al. 2012), these findings support the idea that post-menopausal oestrogen deficiency may, at least circuitously, dispose older females to these age-related ocular diseases.

Published by Bioscientifica Ltd 


\section{Some caveats}

Much of the work concerning oestrogen (particularly $\mathrm{E}_{2}$ ) and its role in human vision have concentrated on the effects of menopause and HRT on visual function. A few studies have also examined the effects of normal cycling oestrogen. The most clear-cut evidence is from studies that have examined the effects of ER positive breast cancer medications (e.g. SERMs) on visual function. Although the majority of studies suggest that oestrogen regulates a range of ocular functions, a clear consensus has yet to emerge. Many of the clinical studies we have reviewed are limited by relatively low numbers of subjects and/or may not have appropriate control groups. Thus the conclusions of these studies must be accepted with these limitations.

Although numerous studies have suggested that oestrogen may be neuroprotective (Azcoitia et al. 2011), and many of the studies we reviewed here suggest that it may be a treatment option in some types of visual dysfunction, this may be a too simplistic view. The Women's Health Initiative (WHI) study on the use of HRT in the USA is a case in point. This study was carried out in postmenopausal women who were treated with conjugated equine oestrogens plus medroxyprogesterone and followed up for 5.2 years only to find that HRT increased the risk of coronary heart disease, breast cancer, stroke and pulmonary embolism (Rossouw 2002). A similar study in the UK came to the same conclusions (Million Women Study; Million Women Study Collaborators 2003). Other studies suggest that giving replacement therapy immediately after menopause may be beneficial (Maki et al. 2011), but that waiting too long after menopause may cause problems (Sherwin 2006, Selvamani \& Sohrabji 2010). The effects of dose and timing of oestrogen treatment in aged females have been reviewed (Azcoitia et al. 2011, Foster 2012) and have been suggested that age-related changes in $\operatorname{ER} \alpha / \operatorname{ER} \beta$ expression, in addition to a reduction in $\mathrm{E}_{2}$, may affect transcription, neuronal growth and neuroprotection (Foster 2012). Another issue in elderly women is the increased number of ER $\alpha$-splice variants, leading to a decline in ER $\alpha$ function (Ishunina \& Swaab 2008). Concomitant treatment with other hormones may be protective, for example the use of oestrogen with progesterone (Acs et al. 2009). On the other hand, some combination therapies may be counter productive (Irwin et al. 2011). Thus, treating visual dysfunction with oestrogen-related drugs may not be a simple procedure.

Although most research has focused on the wellknown nuclear ERs ER $\alpha$ and ER $\beta$, recent research has identified at least one cell-surface GPER and it is possible that other orphan receptors are also targets for oestrogen. It should be noted that $G$ protein-coupled receptors are likely to down-regulate with chronic $\mathrm{E}_{2}$ treatment (Cheng et al. 2005, Hatsumi \& Yamamuro 2006), but this is not always the case (Navarro et al. 2013). In addition, some studies have found $\mathrm{ER} \alpha$ to be located in the cell membrane, and these cell membrane ERs will be faster acting than nuclear ERs.

\section{Conclusions and future directions}

On balance, there is emerging support that endogenous oestrogen plays an important role in ocular pathology and low-level vision. In particular, postmenopausal oestrogen deficiency may lead to increased IOP, which may, in turn, leave older women at increased risk of developing ocular diseases such as glaucoma. In the absence of large-scale and longitudinal studies in humans, there is some way to go before a direct causal link between oestrogen deficiency and visual dysfunction is conclusively established.

Finally, in describing potential cellular protective effects of oestrogen, we have cited many studies from the field of neurobiology, rather than ophthalmology. Apart from the fact that there are many more neurobiology studies describing the protective effects of oestrogen, our reasoning for doing this was that many of the cells in the retina can be considered neuronal and it is likely that many of the mechanisms and intracellular pathways described are important in the eye. To fully understand oestrogen's role in retinal function and health, a major challenge will be to determine the relevant molecular targets. These may be both direct and indirect transcriptional changes and could include miRNAs; ERs can also have repressive, as well as activating, effects at specific promoters. Epigenetic regulation at EREs, which has recently been shown to control oestrogen signalling in breast cancer (Hervouet et al. 2013), adds a further level of complexity.

Declaration of interest

The authors declare that there is no conflict of interest that could be perceived as prejudicing the impartiality of this review.

\section{Funding}

This review did not receive any specific grant from any funding agency in the public, commercial or not-for-profit sector.

Published by Bioscientifica Ltd. 
Acknowledgements

$\mathrm{C} \mathrm{V} \mathrm{H}$ is grateful to the University of Leicester for a period of study leave.

\section{References}

Abramov Y, Borik S, Yahalom C, Fatum M, Avgil G, Brzezinski A \& Banin E 2005 Does postmenopausal hormone replacement therapy affect intraocular pressure? Journal of Glaucoma 14 271-275. (doi:10.1097/ 01.ijg.0000169390.17427.b7)

Acs P, Kipp M, Norkute A, Johann S, Clarner T, Braun A, Berente Z, Komoly S \& Beyer C 2009 17ß-Estradiol and progesterone prevent cuprizone provoked demyelinaton of corpus callosum in male mice. Glia 57 807-814. (doi:10.1002/glia.20806)

Affinito P, Di Spiezio Sardo A, Di Carlo C, Sammartino A, Tommaselli GA, Bifulco G, Loffredo A, Loffredo M \& Nappi C 2003 Effects of hormone replacement therapy on ocular function in postmenopause. Menopause 10 482-487. (doi:10.1097/01.GME.0000063568.84134.35)

Akar Y, Yucel I, Akar ME, Uner M \& Trak B 2005 Long-term fluctuation of retinal sensitivity during pregnancy. Canadian Journal of Ophthalmology 40 487-491. (doi:10.1016/S0008-4182(05)80011-0)

Altintas O, Caglar Y, Yüksel N, Demirci A \& Karabas L 2004 The effects of menopause and hormone replacement therapy on quality and quantity of tear, intraocular pressure and ocular blood flow. Ophthalmologica 218 120-129. (doi:10.1159/000076148)

Arevalo MA, Santos-Galindo M, Lagunas N, Azcoitia I \& Garcia-Segura LM 2011 Selective estrogen receptor modulators as brain therapeutic agents. Journal of Molecular Endocrinology 46 R1-R9. (doi:10.1677/ JME-10-0122)

Azcoitia I, Arevalo MA, De Nicola AF \& Garcia-Segura LM 2011 Neuroprotective actions of estradiol revisited. Trends in Endocrinology and Metabolism 22 467-473. (doi:10.1016/j.tem.2011.08.002)

Carlson LE \& Sherwin BB 2000 Higher levels of plasma estradiol and testosterone in healthy elderly men compared with age-matched women may protect aspects of explicit memory. Menopause 7 168-177. (doi:10.1097/00042192-200007030-00007)

Chen ZG, John M, Subramanian S, Chen H \& Carper D 2004 17- $\beta$-Estradiol confers a protective effect against transforming growth factor- $\beta 2$ induced cataracts in female but not male lenses. Experimental Eye Research 78 67-74. (doi:10.1016/j.exer.2003.09.015)

Cheng G, Li Y, Omoto Y, Wang Y, Berg T, Nord M, Vihko P, Warner M, Piao YS \& Gustafsson JA 2005 Differential regulation of estrogen receptor (ER) $\alpha$ and ER $\beta$ in primate mammary gland. Journal of Clinical Endocrinology and Metabolism 90 435-444. (doi:10.1210/jc.2004-0861)

Coksuer H, Ozcura F, Oghan F, Haliloglu B \& Coksuer C 2011 Effects of estradiol-drospirenone on ocular and nasal functions in postmenopausal women. Climacteric 14 482-487. (doi:10.3109/13697137. 2010.539724)

Colley SM \& Elston JS 2004 Tamoxifen optic neuropathy. Clinical \& Experimental Ophthalmology 32 105-106. (doi:10.1046/j.1442-9071. 2004.00769.x)

Crawford DK, Mangiardi M, Song B, Patel R, Du S, Sofroniew MV, Voskuhl RR \& Tiwari-Woodruff SK 2010 Oestrogen receptor $\beta$ ligand: a novel treatment to enhance endogenous functional remyelination. Brain 133 2999-3016. (doi:10.1093/brain/awq237)

Deschënes MC, Descovich D, Moreau M, Granger L, Kuchel GA, Mikkola TS, Fick GH, Chemtob S, Vaucher E \& Lesk MR 2010 Postmenopausal hormone therapy increases retinal blood flow and protects the retinal nerve fiber layer. Investigative Ophthalmology \& Visual Science $\mathbf{5 1}$ 2587-2600. (doi:10.1167/iovs.09-3710)

Eisner A \& Demirel S 2011 Variability in short-wavelength automated perimetry among peri- and post-menopausal women: a dependence on phyto-oestrogen consumption? Acta Ophthalmologica 89 217-224. (doi:10.1111/j.1755-3768.2009.01799.x)
Eisner A \& Incognito LJ 2006 The color appearance of stimuli detected via short-wavelength-sensitive cones for breast cancer survivors using tamoxifen. Vision Research 46 1816-1822. (doi:10.1016/j.visres.2005. 11.003)

Eisner A \& Luoh SW 2011 Breast cancer medications and vision: effects of treatments for early-stage disease. Current Eye Research 36 867-885. (doi:10.3109/02713683.2011.594202)

Eisner A \& Toomey MD 2008 The color appearance of stimuli detected via short-wavelength-sensitive cones: comparisons with visual adaptation and visual field data for peri- or post-menopausal women under 70 years of age. Vision Research 48 2663-2672. (doi:10.1016/j.visres.2008. 01.029)

Eisner A, Austin DF \& Samples JR 2004 Short wavelength automated perimetry and tamoxifen use. British Journal of Ophthalmology $\mathbf{8 8}$ 125-130. (doi:10.1136/bjo.88.1.125)

Eisner A, Toomey MD, Falaradeau J, Samples JR \& Vetto JT 2007 Differential effects of tamoxifen and anastrozole on optic cup size in breast cancer survivors. Breast Cancer Research and Treatment 106 161-170. (doi:10.1007/s10549-006-9486-3)

Eisner A, Thielman EJ, Falardeau J \& Vetto JT 2009 Vitreo-retinal traction and anastrozole use. Breast Cancer Research and Treatment 117 9-16. (doi:10.1007/s10549-008-0156-5)

Erb C, Gast U \& Schremmer D 2008 German register for glaucoma patients with dry eye: basic outcome with respect to dry eye. Graefe's Archive for Clinical and Experimental Ophthalmology 246 1593-1601. (doi:10.1007/ s00417-008-0881-9)

Espeland MA, Shumaker SA, Limacher M, Rapp SR, Bevers TB, Barad DH, Coker LH, Gaussoin SA, Stefanick ML, Lane DS et al. 2010 Relative effects of tamoxifen, raloxifene, and conjugated equine estrogens on cognition. Journal of Women's Health 19 371-379. (doi:10.1089/jwh. 2009.1605)

Feskanich D, Cho E, Schaumberg DA, Colditz GA \& Hankinson SE 2008 Menopausal and reproductive factors and risk of age-related macular degeneration. Archives of Ophthalmology 126 519-524. (doi:10.1001/ archopht.126.4.519)

Filardo EJ \& Thomas P 2012 G protein-coupled estrogen receptor-1, GPER-1: its mechanism of action and role in female reproductive cancer, renal and vascular physiology. Endocrinology 153 2953-2962. (doi:10.1210/en.2012-1061)

Flammer J, Orgül S, Costa VP, Orzalesi N, Krieglstein GK, Serra LM, Renard JP \& Stefánsson E 2002 The impact of ocular blood flow in glaucoma. Progress in Retinal and Eye Research 21 359-393. (doi:10.1016/S1350-9462(02)00008-3)

Foster TC 2012 Role of estrogen receptor $\alpha$ and $\beta$ expression and signaling on cognitive function during aging. Hippocampus 22 656-669. (doi:10.1002/hipo.20935)

Ganley JP 1980 Epidemiological aspects of ocular hypertension. Survey of Ophthalmology 25 130-135. (doi:10.1016/0039-6257(80)90087-9)

Gharaibeh A, Savage HI, Scherer RW, Goldberg MF \& Lindsley K 2011 Medical interventions for traumatic hyphema. Cochrane Database of Systematic Reviews 1 CD005431. (doi:10.1002/14651858.CD005431.pub2)

Giddabasappa A, Bauler M, Yepuru M, Chaum E, Dalton JT \& Eswaraka J 2010 17- $\beta$ Estradiol protects ARPE-19 cells from oxidative stress through estrogen receptor- $\beta$. Investigative Ophthalmology \& Visual Science 51 5278-5287. (doi:10.1167/iovs.10-5316)

Giordano C, Montopoli M, Perli E, Orlandi M, Fantin M, Ross-Cisneros FN, Caparrotta L, Martinuzzi A, Ragazzi E, Ghelli A et al. 2011 Oestrogens ameliorate mitochondrial dysfunction in Leber's hereditary optic neuropathy. Brain 134 220-234. (doi:10.1093/brain/awq276)

Gordon MO, Beiser JA, Brandt JD, Heuer DK, Higginbotham EJ, Johnson CA, Keltner JL, Miller JP, Parrish RK II, Wilson MR et al. 2002 The ocular hypertension treatment study: baseline factors that predict the onset of primary open-angle glaucoma. Archives of Ophthalmology 120 714-720. (doi:10.1001/archopht.120.6.714)

Guaschino S, Grimaldi E, Sartore A, Mugittu R, Mangino F, Bortoli P, Pensiero S, Vinciguerra A \& Perissutti P 2003 Visual function in 
menopause. The role of hormone replacement therapy. Menopause $\mathbf{1 0}$ 53-57.

Gupta PD, Johar K, Nagpal K \& Vasavada AR 2005 Sex hormone receptors in the human eye. Survey of Ophthalmology 50 274-285. (doi:10.1016/ j.survophthal.2005.02.005)

Haan MN, Klein R, Klein BE, Deng Y, Blythe LK, Seddon JM, Musch DC, Kuller LH, Hyman LG \& Wallace RB 2006 Hormone therapy and age-related macular degeneration - the Women's Health Initiative sight exam study. Archives of Ophthalmology 124 988-992. (doi:10.1001/ archopht.124.7.988)

Hales AM, Chamberlain CG, Murphy CR \& McAvoy JW 1997 Estrogen protects lenses against cataracts induced by transforming group factor- $\beta$. Journal of Experimental Medicine 185 273-280. (doi:10.1084/ jem.185.2.273)

Harris A, Chung HS, Ciulla TA \& Kagemann L 1999 Progress in measurement of ocular blood flow and relevance to our understanding of glaucoma and age-related macular degeneration. Progress in Retinal and Eye Research 18 669-687. (doi:10.1016/S1350-9462(98)00037-8)

Hatsumi T \& Yamamuro Y 2006 Downregulation of estrogen receptor gene expression by exogenous $17 \beta$-estradiol in the mammary glands of lactating mice. Experimental Biology and Medicine 231 311-316.

Hazell GG, Yao ST, Roper JA, Prossnitz ER, O'Carroll AM \& Lolait SJ 2009 Localisation of GPR30, a novel G protein coupled oestrogen receptor, suggests multiple functions in rodent brain and peripheral tissues. Journal of Endocrinology 202 223-236. (doi:10.1677/JOE-09-0066)

Hervouet E, Cartron PF, Jouvenot M \& Delage-Mourroux R 2013 Epigenetic regulation of estrogen signaling in breast cancer. Epigenetics $\mathbf{8} 237-245$. (doi:10.4161/epi.23790)

Hulsman CA, Westendorp IC, Ramrattan RS, Wolfs RC, Witteman JC, Vingerling JR, Hofman A \& de Jong PT 2001 Is open-angle glaucoma associated with early menopause? The Rotterdam Study American Journal of Epidemiology 154 138-144. (doi:10.1093/aje/154.2.138)

Irwin RW, Yao J, Ahmed SS, Hamilton RT, Cadenas E \& Brinton RD 2011 Medroxyprogestreone acetate antagonizes estrogen up-regulation of brain function. Endocrinology 152 556-567. (doi:10.1210/en.2010-1061)

Ishunina TA \& Swaab DF 2008 Estrogen receptor $\alpha$ splice variants in the human brain. Gynecological Endocrinology 24 93-98. (doi:10.1080/ 09513590701705148)

Johnson N \& Petersik JT 1987 Preliminary findings suggesting cyclic changes in visual contrast sensitivity during the menstrual cycle. Perceptual and Motor Skills 64 587-594. (doi:10.2466/pms.1987.64.2.587)

Jover-Mengual T, Zukin RS \& Etgen AM 2007 MAPK signaling is critical to estradiol protection of CA1 neurons in global ischemia. Endocrinology 148 1131-1143. (doi:10.1210/en.2006-1137)

Kamalden TA, Ji D, Fawcett RJ \& Osborne NN 2011 Genistein blunts the negative effect of ischaemia to the retina caused by an elevation of intraocular pressure. Ophthalmic Research 45 65-72. (doi:10.1159/ 000313985)

Kanthan GL, Wang JJ, Burlutsky G, Rochtchina E, Cumming RG \& Mitchell P 2010 Exogenous oestrogen exposure, female reproductive factors and the long-term incidence of cataract: the Blue Mountains Eye Study. Acta Ophthalmologica 88 773-778. (doi:10.1111/j.1755-3768. 2009.01565.x)

Kass MA, Heuer DK, Higginbotham EJ, Johnson CA, Keltner JL, Miller JP, Parrish RK II, Wilson MR \& Gordon MO 2002 The ocular hypertension treatment study: a randomized trial determines that topical ocular hypotensive medication delays or prevents the onset of primary open-angle glaucoma. Archives of Ophthalmology 120 701-713. (doi:10.1001/archopht.120.6.701)

Kavroulaki D, Gugleta K, Kochkorov A, Katamay R, Flammer J \& Orgul S 2010 Influence of gender and menopausal status on peripheral and choroidal circulation. Acta Ophthalmologica 88 850-853. (doi:10.1111/ j.1755-3768.2009.01607.x)

Khurana RN, LaBree LD, Scott G, Smith RE \& Yiu SC 2006 Esterified estrogens combined with methyltestosterone raise intraocular pressure in postmenopausal women. American Journal of Ophthalmology 142 494-495. (doi:10.1016/j.ajo.2006.04.018)

Klinge CM 2008 Estrogenic control of mitochondrial function and biogenesis. Journal of Cellular Biochemistry 105 1342-1351. (doi:10.1002/jcb.21936)

Lee SM, Tseng LM, Li AF, Liu HC, Liu TY \& Chi CW 2004 Polymorphism of estrogen metabolism genes and cataract. Medical Hypotheses 63 494-497. (doi:10.1016/j.mehy.2004.02.044)

Mabuchi F, Sakurada Y, Kashiwagi K, Yamagata Z, Iijima H \& Tsukahara S 2010 Estrogen receptor $\beta$ polymorphism and intraocular pressure elevation in female patients with primary open-angle glaucoma. American Journal of Ophthalmology 149 826-830. (doi:10.1016/ j.ajo.2009.12.030)

Maki PM, Dennerstein L, Clark M, Guthrie J, LaMontagne P, Fornelli D, Little D, Henderson VW \& Resnick SM 2011 Perimenopausal use of hormone therapy is associated with enhanced memory and hippocampal function later in life. Brain Research 1379 188-198. (doi:10.1016/j.brainres.2010.11.030)

Manavathi B \& Kumar R 2006 Steering estrogen signals from the plasma membrane to the nucleus: two sides of the coin. Journal of Cellular Physiology 207 594-604. (doi:10.1002/jcp.20551)

Million Women Study Collaborators 2003 Breast cancer and hormone replacement therapy in the Million Women Study. Lancet 362 419-427. (doi:10.1016/S0140-6736(03)14065-2)

Nakazawa T, Takahashi H \& Shimura M 2006 Estrogen has a neuroprotective effect on axotomized RGCs through ERK signal transduction pathway. Brain Research 1093 141-149. (doi:10.1016/j.brainres.2006. 03.084)

Navarro A, Del Valle E, Ordóñez C, Martínez E, Pérez C, Alonso A, González C \& Tolivia J 2013 Aging and substitutive hormonal therapy influence in regional and subcellular distribution of $\mathrm{ER} \alpha$ in female rat brain. Age 35 821-837. (doi:10.1007/s11357-012-9415-9)

Nayfield SG \& Gorin MB 1996 Tamoxifen-associated eye disease: a review. Journal of Clinical Oncology 14 1018-1026.

Neumann F, Wurm A, Linnertz R, Pannicke T, Iandiev I, Wiedemann P, Reichenbach A \& Bringmann A 2010 Sex steroids inhibit osmotic swelling of retinal glial cells. Neurochemical Research 35 522-530. (doi:10.1007/s11064-009-0092-8)

Nixon E \& Simpkins JW 2012 Neuroprotective effects of nonfeminizing estrogens in retinal photoreceptor neurons. Investigative Ophthalmology \& Visual Science 53 4739-4747. (doi:10.1167/iovs.12-9517)

Noureddin BN, Seoud M, Bashshur Z, Salem Z, Shamseddin A \& Khalil A 1999 Ocular toxicity in low-dose tamoxifen: a prospective study. Eye $\mathbf{1 3}$ 729-733. (doi:10.1038/eye.1999.217)

Orwoll E, Lambert LC, Marshall LM, Phipps K, Blank J, Barrett-Connor E, Cauley J, Ensrud K \& Cummings S 2006 Testosterone and estradiol among older men. Journal of Clinical Endocrinology and Metabolism 91 1336-1344. (doi:10.1210/jc.2005-1830)

Özcura F, Dündar SO, Çetin ED, Beder N \& Dündar M 2012 Effects of estrogen replacement therapy on apoptosis and vascular endothelial growth factor expression in ocular surface epithelial cells: an experimental study. International Journal of Ophthalmology 5 64-68. (doi:10.3980/j.issn.2222-3959.2012.01.13)

Paganini-Hill A \& Clark LJ 2000 Eye problems in breast cancer patients treated with tamoxifen. Breast Cancer Research and Treatment 2 167-172. (doi:10.1023/A:1006342300291)

Pasquale LR, Rosner BA, Hankinson SE \& Kang JH 2007 Attributes of female reproductive aging and their relation to primary open-angle glaucoma: a prospective study. Journal of Glaucoma 16 598-605. (doi:10.1097/IJG. Ob013e318064c82d)

Pinto L, Abegao VE \& Stalmans I 2012 Disturbed correlation between arterial resistance and pulsatility in glaucoma patients. Acta Ophthalmologica 90 e214-e220. (doi:10.1111/j.1755-3768.2011.02335.x)

Pointer JS 2000 Evidence that a gender difference in intraocular pressure is resent from childhood. Ophthalmic \& Physiological Optics 20 131-136. (doi:10.1016/S0275-5408(99)00042-3) 
de Ronde W, Pols HA, van Leeuwen JP \& de Jong FH 2003 The importance of oestrogen in males. Clinical Endocrinology 58 529-542. (doi:10.1046/ j.1365-2265.2003.01669.x)

Queseda A, Lee BY \& Micevych PE 2008 PI3 kinase/Akt activation mediates estrogen and IGF-1 nigral DA neural neuroprotection against a unilateral rat model of Parkinson's disease. Developmental Neurobiology 68 632-644. (doi:10.1002/dneu.20609)

Qureshi IA, Huang YB, Xi XR \& Wu XD 1997 Hormonal changes associated with menstrual cycle have no definite influence on ocular pressure. Proceedings of the National Science Council, Republic of China. Part B, Life Sciences 21 49-53.

Rossouw JE 2002 Hormones for coronary disease - full circle. Lancet 360 1996-1997. (doi:10.1016/S0140-6736(02)12030-7)

Russo R, Cavaliere F \& Watanabe C 2008 17 $\beta$-Estradiol prevents retinal ganglion cell loss induced by acute intraocular pressure in rate. Progress in Brain Research 173 583-590. (doi:10.1016/S0079-6123(08)01144-8)

Salomao SR, Watanabe SE, Berezovsky A \& Motono M 2007 Multifocal electroretinography, color discrimination and ocular toxicity in tamoxifen use. Current Eye Research 32 345-352. (doi:10.1080/ 02713680701229638)

Salvati AL 1923 Influence de la menstruation sur la tension oculaire. Annales d'Oculistique 160 568-569.

Sanchez AM \& Simoncini T 2010 Extra-nuclear signaling of ER $\alpha$ to the actin cytoskeleton in the central nervous system. Steroids 75 528-532. (doi:10.1016/j.steroids.2009.12.003)

Sator MO, Joura EA, Golaszewski T, Gruber D, Frigo P, Metka M, Hommer A \& Huber JC 1998 Treatment of menopausal keratoconjunctivitis sicca with topical oestradiol. British Journal of Obstetrics and Gynaecology $\mathbf{1 0 5}$ 100-102. (doi:10.1111/j.1471-0528.1998.tb09358.x)

Schaumberg DA, Buring JE, Sullivan DA \& Dana MR 2001 Hormone replacement therapy and dry eye syndrome. Journal of the American Medical Association 286 2114-2119. (doi:10.1001/jama.286.17.2114)

Selvamani A \& Sohrabji F 2010 The neurotoxic effects of estrogen on ischemic stroke in older female rats is associated with age dependent loss of insulin-like growth factor-1. Journal of Neuroscience $\mathbf{3 0}$ 6852-6861. (doi:10.1523/JNEUROSCI.0761-10.2010)

Seymenoğlu G, Baser EF, Zerdeci N \& Gülhan C 2011 Corneal biomechanical properties during the menstrual cycle. Current Eye Research 36 399-403. (doi:10.3109/02713683.2011.553307)

Sherwin BB 2006 Estrogen and cognitive aging in women. Neuroscience 138 1021-1026. (doi:10.1016/j.neuroscience.2005.07.051)

Shoshani YZ, Harris A, Rusia D, Spaeth GL, Siesky B, Pollack A \& Wirostko B 2011 Contrast sensitivity, ocular blood flow and their potential role in assessing ischaemic retinal disease. Acta Ophthalmologica 89 e382-e395. (doi:10.1111/j.1755-3768.2011.02130.x)

Siesky BA, Harris A, Patel C, Klaas CL, Harris M, McCranor LJ, Lauer J \& Kaplan B 2008 Comparison of visual function and ocular hemodynamics between pre- and post-menopausal women. European Journal of Ophthalmology 18 320-323.

Simpkins JW, Yi KD, Yang SH \& Dykens JA 2010 Mitochondrial mechanisms of estrogen neuroprotection. Biochimica et Biophysica Acta 1800 1113-1120. (doi:10.1016/j.bbagen.2009.11.013)

van der Spuy WJ \& Pretorius E 2012 Interrelation between inflammation, thrombosis, and neuroprotection in cerebral ischemia. Reviews in the Neurosciences 23 269-278. (doi:10.1515/revneuro-2012-0028)
Taner P, Akarsu C, Atasoy P, Bayram M \& Ergin A 2004 The effects of hormone replacement therapy on ocular surface and tear function tests in postmenopausal women. Ophthalmologica 218 257-259. (doi:10.1159/000078616)

Tint NL, Alexander P, Tint KM, Vasileiadis GT, Yeung AM \& Azuara-Blanco A 2010 Hormone therapy and intraocular pressure in nonglaucomatous eyes. Menopause 17 157-160. (doi:10.1097/gme. Ob013e3181b82fb4)

Tiwari-Woodruff S \& Voskuhl RR 2009 Neuroprotective and antiinflammatory effects of estrogen receptor ligand treatment in mice. Journal of the Neurological Sciences 223 15-622.

Uncu G, Avci R, Uncu Y, Kaymaz C \& Develioglu O 2006 The effects of different hormone replacement therapy regimens on tear function, intraocular pressure and lens opacity. Gynecological Endocrinology 22 501-505. (doi:10.1080/09513590600917919)

Vasconsuelo A, Pronsato L, Ronda AC, Boland R \& Milanesi L 2011 Role of $17 \beta$-estradiol and testosterone in apoptosis. Steroids 76 1223-1231. (doi:10.1016/j.steroids.2011.08.001)

Versura P \& Campos EC 2005 Menopause and dry eye: a possible relationship. Gynecological Endocrinology 20 289-298. (doi:10.1080/ 09513590400027257)

de Voogd S, Wolfs RC, Jansonius NM, Uitterlinden AG, Pols HA, Hofman A $\&$ de Jong PT 2008 Estrogen receptors $\alpha$ and $\beta$ and the risk of open angle glaucoma: the Rotterdam Study. Archives of Ophthalmology 126 110-114. (doi:10.1001/archopht.126.1.110)

Wang C, Shi X, Chen X, Wu H, Zhang H, Xie J, Yang X, Gou Z \& Ye J 2012 $17-\beta$-Estradiol inhibits hyperosmolarity-induced proinflammatory cytokine elevation via the p38 MAPK pathway in human corneal epithelial cells. Molecular Vision 18 1115-1122.

Wankun X, Wenzhen Y, Min Z, Weiyan Z, Huan C, Wei D, Lvzhen H, Xu Y $\&$ Xiaoxin L 2011 Protective effect of paeoniflorin against oxidative stress in human retinal pigment epithelium in vitro. Molecular Vision 17 3512-3522.

Wei X, Cai SP, Zhang X, Li X, Chen X \& Liu X 2012 Is low dose of estrogen beneficial for prevention of glaucoma? Medical Hypotheses 79 377-380. (doi:10.1016/j.mehy.2012.05.041)

Wickam LA, Gao J, Toda I, Rocha EM, Ono M \& Sullivan DA 2000 Identification of androgen, estrogen and progesterone receptor mRNAs in the eye. Acta Ophthalmologica Scandinavica 78 146-153. (doi:10.1034/j.1600-0420.2000.078002146.x)

Worzala K, Hiller R, Sperduto RD, Mutalik K, Murabito JM, Moskowitz M, D'Agostino RB \& Wilson PW 2001 Postmenopausal estrogen use, type of menopause, and lens opacities - the Framingham studies. Archives of Internal Medicine 161 1448-1454. (doi:10.1001/archinte.161. 11.1448)

Yamashita H, Yamada-Nakayama C, Sugihara K, Tsuji S, Sakurai T, Ban Y, Tsutsumi S \& Sato Y 2011 Functional and morphological effects of $\beta$-estradiol in eyes with $N$-methyl-D-aspartate-induced retinal neurotoxicity in rats. Experimental Eye Research 93 75-81. (doi:10.1016/j.exer. 2011.04.006)

Yang LC, Zhang QG, Zhou CF, Yang F, Zhang YD, Wang RM \& Brann DW 2010 Extranuclear estrogen receptors mediate the neuroprotective effects of estrogen in the rat hippocampus. PLOS ONE 5 e9851. (doi:10.1371/journal.pone.0009851)

Received in final form 12 August 2014

Accepted 20 August 2014

Accepted Preprint published online 20 August 2014 http://joe.endocrinology-journals.org DOI: 10.1530/JOE-14-0349
() 2014 Society for Endocrinology Printed in Great Britain 